\title{
Climate Change and Health in Canada
}

\author{
Lea Berrang Ford*
}

\section{INTRODUCTION}

National governments from around the world met in Poznan, Poland in December 2008 at the 14th Conference of the Parties to the United Nations Framework Convention on Climate Change (1). This conference came at a time of increasing political and scientific confidence in the role of human-induced greenhouse gas emissions in changing global temperatures. The most recent (2007) report of the Intergovernmental Panel on Climate Change (2) states that climate change is now "unequivocal", based on increasing evidence from global average air and ocean temperatures, melting of snow and ice, and rising global average sea level" (2). While there remains uncertainty regarding the specific nature and rate of climatic changes and their impacts, there is negligible scientific doubt that the global climate is changing and that these changes will have significant and potentially profound impacts on a wide range of ecological and human systems across the planet (3-6).

That climate change predictions are both scientifically and politically daunting lessens neither their verity nor implied imperative $(7,8)$. Climate change will involve an average increase in global temperatures of approximately $1.1-6.4^{\circ} \mathrm{C}$ by the end of the century (1); this range reflects both uncertainty in climate modeling, as well as a range of possible scenarios for how we will respond to climate changes, including mitigation, technology development, economic development and population growth. This temperature shift will be manifest in average global climatic changes, including higher maximum temperature, more very hot days, increased occurrence and severity of heat waves, fewer cold and frost days, fewer cold spells, more intense precipitation events, increased risk of drought in

*To whom correspondence should be addressed:

Dr. Lea Berrang Ford

Department of Geography

McGill University

Burnside Hall Rm. 705

805 Sherbrooke Street Ouest

Montreal, QC, H3A 2K6 continental areas, increased cyclone intensities, and intensified ENSO events. These effects will, however, vary significantly by region and act within existing climate conditions. For example, while parts of Latin America will see minimal changes in temperature, Arctic regions are expected to experience an average temperature shift of $4-7^{\circ} \mathrm{C}$ by the end of the century (9) and recent research suggests that even these projections may be conservative $(6,10)$.

Changes in our global and regional climate systems will have important implications for health and health systems (11-22). The World Health Organization estimated that in the year 2000, climate change caused approximately 150,000 excess deaths worldwide, as well as 5 million disability-adjusted life years (19). Temperature and weather have direct effects on mortality and morbidity through the occurrence of extreme weather events, including heatwaves, cold periods, storms, floods, and droughts $(11,23-25)$. Such events can, in turn, affect the incidence of food-borne and water-borne disease $(26,27)$. The habitat and survival of insect species capable of transmitting many vector-borne diseases are affected by temperature and water regimes $(28,29)$. Many pathogen replication cycles are also determined by temperature conditions. Indirect impacts of climate change on livelihoods, such as increased economic vulnerability, reduced availability of food resources, and reduced allocation of government funding for health systems, may also have important, though unquantified, impacts on global health systems $(2,12,14,18,20,30)$.

Health impacts due to climate change have already been documented, including changes in the range of some vector-borne diseases $(28,29,31-33)$ and an increase in heatwave-related deaths $(11,34,35)$. Indirect effects will also include increases in regional food insecurity, migration resulting from environmental degradation, and loss of environmental-dependent livelihoods resulting from ecological shifts in weather or species distributions (16). Table 1 summarizes the reported and projected health impacts of climate change documented by the Intergovernmental Panel on Climate 
Change (IPCC). The IPCC, an intergovernmental body open to all United Nations member countries, comprehensively assesses existing literature related to climate change science, potential impacts, and options for adaptation and mitigation. The published reports represent the consensus of thousands of scientists around the world contributing as authors and reviewers, as well as political consensus required by member countries for the acceptance, adoption and approval of the final document. These projections and measures of confidence are therefore believed to be conservative (3$5)$.

Current climate change effects on global health are small but increasing in most countries (16). This is due to the lag effect between greenhouse-gas emissions, climate system warming, and the weight of evidence documenting health impacts. While the burden of negative health impacts will be disproportionately high in poorer countries, even high-income countries will be vulnerable to morbidity and mortality related to increases in the number and severity of extreme weather events such as storms, heatwaves, and floods (16). Vulnerable populations in all countries include the urban poor, the elderly and children, traditional communities, subsistence farming communities, and coastal populations $(16,21,36-38)$. Evidence does not support the potential for economic development to combat the health impacts of climate change (16).

\section{CLIMATE CHANGE AND HEALTH IN CANADA}

Canada will not be immune to the health impacts of climatic change (39-42). Canada has observed approximately $1^{\circ} \mathrm{C}$ rise in temperature since the beginning of the century, and we can expect this to continue by about 0.5 degree per decade, up to $5^{\circ} \mathrm{C}$ over the next century (42). This temperature change is not insignificant; the earth's temperature was, for example, only 4-5 degrees cooler during the last ice age (43).

The effects of climate change in Canada will differ between regions (42). While the Prairies are expected to experience warmer, drier summers and more sever summer droughts, Ontario and Quebec can expect decreased snow, increased rainfall, and an increase in the incidence of severe summer storms (44). The greatest changes will occur in the Canadian North, where temperature changes are projected to be among the highest in the world, and where traditional, resource-dependent communities are considered highly vulnerable $(9,42,45,46)$. Indeed, for northern Inuit communities, climate change poses a significant threat to traditional livelihoods in the short to medium term (45, 47-49).

Canada will experience a number of significant direct and indirect impacts of climate change (39-42). Extreme heat events are expected to become more frequent, longer in duration, and more intense (42). Extreme heat events can exacerbate health conditions, such as asthma, as well as lead to an increased number of deaths $(11,23,50,51)$. Heat waves were responsible for over five hundred deaths in Chicago during a 5-day

\begin{tabular}{|l|l|}
\hline Existing impacts & Level of uncertainty * \\
\hline Alter the distribution of some infectious disease vectors & Medium confidence \\
\hline Alter the seasonal distribution of some allergenic pollen species & High confidence \\
\hline Increase heatwave-related deaths & Medium confidence \\
\hline Projected impacts & High confidence \\
\hline Increase in malnutrition and consequent disorders, including child growth and development & High confidence \\
\hline Increase in morbidity and mortality related to heatwaves, floods, storms, fires, and droughts & High confidence \\
\hline Continued changes in the ranges of some infectious disease vectors & Very high confidence \\
\hline Mixed effects on malaria incidence and distribution (expansion in some areas, contraction in others) & Medium confidence \\
\hline Increase in the burden of diarrhoeal diseases & High confidence \\
\hline Increase in cardio-respiratory morbidity and morality associated with ground-level ozone & Low confidence \\
\hline Increase in the number of people at risk of dengue & High confidence \\
\hline Health benefits include fewer deaths due to cold & \\
\hline
\end{tabular}

Table 1: Summary of the health impacts of climate change, based on the Intergovernmental Panel on Climate Change Assessment Report Four (16).

* Degree of confidence in being correct: Very high confidence $>9$ out of 10 chance; High confidence $\sim 8$ out of 10 chance; Medium confidence $\sim 5$ out of 10 chance; Low confidence $\sim 2$ out of 10 chance (16). 
period in 1995 (52) and at least 50,000 deaths in Europe in 2003 (53). Children and the elderly are particularly vulnerable during heat wave events (54). The increasing number of summer days in urban areas of Quebec and Ontario declared unsafe for outdoor activity due to smog and heat can be expected to negatively impact public health through reduced outdoor and exercise activities (55). Poor air quality, resulting from smog and air pollution, is associated with asthma, chronic respiratory disease and cardiovascular disease, and is a serious public health issue in Canada. Smog and air pollution are expected to continue to increase with climatic change $(23,56)$. Toronto public health recently predicted that climate change would cause a $20 \%$ increase in air-pollution related deaths in the city by 2050 (57).

Many regions are expected to see an increase in summer storms. This may affect risks associated with flooding, and will have implications for water quality and contamination $(26,58-60)$. A prolonged drought followed by a high rainfall event - such as a summer storm - can pick up surface contaminants and flush them into local waterways, causing a 'pulse' in the contaminant load of local water treatment facilities (26, 40). This scenario was determined to be one of the factors contributing to the $\mathrm{E}$. coli outbreak in Walkerton, Ontario in 2000 (61). In addition, higher than normal rainfall events may exceed expected norms for sewage treatment facilities, overwhelming treatment systems. In the Inuit community of Arctic Bay, increased rainfall has been observed to overflow the local sewage ponds, contaminating the bay and roads (62). These scenarios are consistent with climate change predictions and can be expected to occur more frequently.

The distribution of vector-borne diseases will change (40, 41, 63-65). Warmer and wetter summers will affect the distribution and survival of pathogens and some disease vectors such as mosquitoes and ticks $(39,66-$ 68 ). Research has already documented possible shifts in the distribution of the vector of Lyme disease $(29,69$ 71), and possible expansion of the potential range of West Nile virus (WNV) $(40,41,72)$. Mosquito vectors of WNV will be affected by longer summers $(40,41)$. Increased incidence of the virus coincides with periods of prolonged hot weather and increased mosquito activity (73). Recent research also indicates the potential for the re-emergence or emergence of exotic pathogens to Canada, including locally-transmitted malaria (63). Emergent disease risks are by nature difficult to predict. Despite this, it is sensible to anticipate the spread of known diseases into new areas and the emergence of new diseases.

There will also be a number of indirect effects on
Canadian health and health care. In many cases, these indirect pathways are difficult to identify, predict, and quantify, but may nonetheless be important for changing health systems in Canada. For example, changing sea temperatures are likely to impact the distribution and availability of fish and tree species through impacts on local weather, affecting the viability or focus of fisheries and forestry industries, and by extension the community health and well-being of resource-dependent communities. In this case, the concern is not the loss of traditional species per se new species are likely to emerge to fill changing niche conditions - but the rate of change in ecological systems, and the ability of industries and communities to adapt to these changes. Similarly, the dramatic spread of the pine beetle has been facilitated - and many suggest triggered - by increasingly favourable weather conditions (74-77). As in the case of the pine beetle, many of the impacts of climate change on health in Canada are likely to be the result of indirect causal processes, and in some cases unforeseen events.

The implications of climate change for health are not limited to global and national impacts. They will also be manifest at the municipal level (Table 2) and within Canada's health sector $(41,55,78)$. For Canada's health system, this will result in changing risks. For example,

\begin{tabular}{|c|c|}
\hline Sector & Health determinants \\
\hline \multirow[t]{2}{*}{ Social } & Social status \\
\hline & Social support networks \\
\hline \multirow[t]{3}{*}{ Economic } & Income \\
\hline & Employment \\
\hline & Working conditions \\
\hline \multirow[t]{7}{*}{ Environmental } & Air quality \& air pollution \\
\hline & Drinking water quality \\
\hline & Recreational water quality \\
\hline & Water availability \\
\hline & Food safety \& inspection \\
\hline & Regional parks \\
\hline & Environmental planning \& impact analysis \\
\hline \multirow{6}{*}{$\begin{array}{l}\text { Infrastructure and } \\
\text { local works }\end{array}$} & Housing \\
\hline & Indoor air quality \\
\hline & Vector-control \\
\hline & Land use planning \& urban development \\
\hline & Water distribution, recycling \& disposal \\
\hline & Sewage treatment \& inspection \\
\hline \multirow[t]{2}{*}{ Transport } & Public transportation \\
\hline & Transportation systems and road works \\
\hline \multirow[t]{2}{*}{ Emergency response } & Emergency \& disaster preparedness \\
\hline & Outbreak investigation \\
\hline
\end{tabular}

Table 2: Health determinants affected by climate change 
the increased emergence of new, re-emergent and exotic diseases will mean that conventional expectations of likely diagnoses by family physicians and primary health care providers will be insufficient. The potential for malaria infection in patients with no history of travel is one such example (63). The increase in extreme weather events such as heatwaves, floods and storms will increase pressure on disaster preparedness and emergency health services and programming (79). Program planning for emergency health provision will need to consider future rather than historical experiences or trends in demand and frequency of health crises $(34,80-82)$. Increased health surveillance will be required to document baseline health measures and monitor changing health outcomes. This is particularly important in Canada's northern communities where health provision and surveillance have faced significant challenges and where climate impacts will develop earlier and more rapidly than in the South $(83,84)$.

\section{RESPONSES}

The good news is that opportunities for avoidance of, and adaptation to, climate impacts on health are available, feasible, and in many cases of benefit to improved health in Canada more broadly (42). Given the unpredictable nature of many impacts, adaptation, prevention, and preparedness measures that increase overall health system capacity are most sensible and cost-effective - so called 'win win' or 'no regrets' responses $(18,85-89)$. These include: Increased surveillance, particularly of disease vectors, water quality, and air pollutants; Integration of climate projections into emergency planning and disaster preparedness (79); Improved access to preventive care and primary physician care to promote early detection of new disease emergence or shifting disease incidence; Integration of climate change considerations into education programming for medical students and primary health care workers; Integration of climate projection parameters into urban planning to increase protection against extreme weather events $(55,90-92)$; Increased monitoring and evaluation of food production systems and water monitoring safety given climate projections $(26,41,63,68)$; Development of heat wave alerts and responses, and mitigation of urban heat islands $(41,52,53,91)$, and; Increased multi-national support for improved health capacity in low and middle income countries.

The risk of health impacts resulting from climate change are not restricted to within our national borders. The impact of climate change elsewhere, particularly in low and middle income nations, will influence the potential for imported infection to Canada. For example, the introduction and outbreak of SARS in Toronto in 2002 resulted in 438 cases, 44 deaths and significant economic losses $(93,94)$. International travel may have been responsible for promoting the introduction of West Nile virus in North America (9597). Similarly, a Canadian outbreak of imported malaria in 1995-97 may have been brought to Canada via travelers arriving from the Punjab in India, where a large epidemic had occurred $(63,98-100)$. More recently, concern regarding the potential spread or proliferation of avian influenza has highlighted the interconnected nature of national health to health conditions around the world. As such, the health impacts of climate change in Canada will be influenced by the health and response capacity of other nations from or to which Canadians, visitors or trade products travel. In this context, adaptation, preparedness and response resources may in some cases be most effectively and efficiently allocated through supporting health capacity in other countries. Increased interest and prioritization of health collaborations in Asia following the SARS outbreak provides a germane example of a developing awareness of such risk priorities.

Despite the magnitude and scope of climate change, the recent global financial crisis has overshadowed concern for, and prioritization of, climate change science, policy, and action. While the implications of economic crisis at the international and national levels are undoubtedly of legitimate priority and concern, placing climate issues on the back-burner is misguided for two reasons. First, while the financial crisis may be acute and possibly prolonged in the short term -years, but not decades - the climate change crisis will last well into the next century and beyond. Investments in health system capacity and surveillance need to be implemented in advance of emerging impacts to avoid and/or mitigate morbidity and mortality. Additionally, observed climate impacts will begin to rapidly accelerate over the next decade. In the absence of genuine and dramatic intervention, climate change impacts have the potential to be severe and acute on a scale greatly exceeding the current financial crisis $(3,4$, $6,7)$. The lack of action on climate change - including both mitigation of emissions and adaptation to current and future impacts - is generally rationalized based on the costs of interventions. The costs of a no-action approach, however, will be significant. The Stern Review, an independent assessment commissioned in the United Kingdom, estimated that a $5-6{ }^{\circ} \mathrm{C}$ warming over the next century could result in losses of up to $20 \%$ of global GDP (101); the report estimates the cost of mitigating climate emissions and severe impacts at approximately $1 \%$ of global GDP. The health sector, which makes up $10 \%$ of Canada's Gross National 
Product (GNP) can make a significant contribution to climate change mitigation and adaptation in Canada $(102,103)$.

It is no longer sufficient to use our past climate experiences to assess health risks and health system requirements. Future health systems and care will need to reflect changing risk conditions; these will differ from what physicians, primary care professionals, and public health professionals are accustomed to. Climate will emerge in the next years and decades as an increasingly important determinant of individual and public health in Canada. Reduced individual and national contributions to greenhouse gas emissions to avoid severe impacts, combined with proactive planning and programming for adaptation will be required.

\section{REFERENCES}

1. IPCC. Climate Change 2007: The Physical Science Basis. Contribution of Working Group I to the Fourth Assessment Report of the Intergovernmental Panel on Climate Change. Geneva; 2007.

2. IPCC. Climate change 2007: Impacts, Adaptation and Vulnerability, Summary for Policy Makers. Brussels: Intergovernmental Panel on Climate Change; 2007.

3. Schellnhuber HJ. Global warming: Stop worrying, start panicking? Proceedings of the National Academy of Sciences of the United States of America. 2008;105(38):14239-40.

4. Ramanathan V, Feng Y. On avoiding dangerous anthropogenic interference with the climate system: Formidable challenges ahead. Proceedings of the National Academy of Sciences of the United States of America. 2008;105(38):14245-50.

5. May W. Climatic changes associated with a global $" 2{ }^{\circ} \mathrm{C}$ stabilization" scenario simulated by the ECHAM5/ MPI-OM coupled climate model. Climate Dynamics. 2008;31(2-3):283313.

6. Lenton TM, Held H, Kriegler E, Hall JW, Lucht W, Rahmstorf $\mathrm{S}$, et al. Inaugural Article: Tipping elements in the Earth's climate system. 2008:1786-93.

7. Stern N. The Economics of Climate Change: The Stern Review. Cambridge Cambridge University Press 2006.

8. Stern N, Taylor C. Climate change: Risks, ethics, and the Stern Review. Science. 2007;317:203-4.

9. ACIA. Arctic Climate Impacts Assessment. Cambridge, UK: Cambridge University Press 2005.

10. Lawrence DM, Slater AG, Tomas RA, Holland MM, Deser C. Accelerated Arctic land warming and permafrost degradation during rapid sea ice loss. Geophysical Research Letters. 2008;35(11).

11. Basu R, Samet J. Relations between elevated ambient temperature and mortality: a review of the epidemiological evidence. Epidemiologic Reviews. 2002;24:190-202.

12. Campbell-Lendrum C, Woodruff R. Climate change: quantifying the health impacts at national and local levels. Environmental Burden of Disease Series, World Health Organization. 2007;14.

13. Ebi K, Semenza J. Community-based adaptation to the health impacts of climate change. American Journal of Preventive Medicine. 2008;35(5):501-07.

14. Epstein P. Climate change and emerging infectious diseases. Microbes Infect. 2001;3:747-54

15. Frumkin H, McMichael A, Hess J. Climate change and the health of the public. American Journal of Preventive Medicine. 2008;35(5):401-02.

16. IPCC. Climate Change 2007: Impacts, Adaptation and Vulnerability. Contribution of Working Group II to the Fourth Assessment Report of the Intergovernmental Panel on Climate Change: Working Group II. Cambridge, UK: Cambridge University Press; 2007.

17. Keim M. Building human resilience: the role of public health preparedness and response as an adaptation to climate change. American Journal of Preventive Medicine. 2008;35(5):508-16.

18. McMichael A, Campbell-Lendrem D, Corvalan C, Ebi K, Githeko A, Scheraga J, et al. Climate change and human health - risk and responses. Geneva: World Health Organization 2003.

19. McMichael A, Campbell-Lendrum D, Kovats S, Edwards S, Wilkinson P, Wilson T, et al. Climate Change. In: Ezzati M, Lopez A, Rodgers A, Mathers C, eds. Comparative quantification of health risks: global and regional burden of disease due to selected major risk factors. Geneva: World Health Organization 2004:1543-649.

20. McMichael AJ, Woodruff RE, Hales S. Climate change and human health: present and future risks The Lancet. 2006;367(9513):859-69.

21. Patz J, Campbell-Lendrum D, Holloway T, Foley J. Impact of regional climate on human health. Nature. 2005;438(7066):31017.

22. Patz J, Kovats F. Hotspots in climate change and human health. BMJ. 2002;325:1094-98.

23. Luber G, McGeehin M. Climate change and extreme health events. American Journal of Preventive Medicine. 2008;35(5):429-35.

24. Braga A, Zanobetti A, Schwartz J. The effect of weather on respiratory and cardiovascular deaths in 12 US cities. Environmental Health Perspectives 2002;110:859-63.

25. Curriero F, Heiner K, Samet J, Zeger S, Strug L, Patz J. Temperature and mortality in 11 cities of the Eastern United States. American Journal of Epidemiology. 2002;155:80-7.

26. Charron D, Thomas M, Waltner-Toews D, Aramini J, Edge T, Kent R, et al. Vulnerability of waterborne diseases to climate change in Canada: A review Journal of Toxicology and Environmental Health - Part A - Current Issues. 2004;67(2022):1667-77.

27. D'Souza R, Beeker N, Hall G, Moodie K. Does ambient temperature affect foodborne disease? Epidemiology. 2004;15(1):86-92.

28. Martens W, Jetten T, Rotmans J, Niessen L. Climate change and vector-borne disease. Global Environmental Change. 1995;5:195.

29. Ogden NH, Maarouf A, Barker IK, Bigras-Poulin M, Lindsay LR, Morshed MG, et al. Climate change and the potential for range expansion of the Lyme disease vector Ixodes scapularis in Canada. International Journal for Parasitology. 2006;36:63-70.

30. McMichael A. Detecting the health effects of environmental change: scientific and political challenge. EcoHealth. 2005;2:13.

31. Kovats R, Campbell-Lendrum D, McMichel A, Woodward A, Cox J-H. Early effects of climate change: do they include changes in vector-borne disease? Philosophical Transactions of the Royal Society of London B. 2001;356:1057-68.

32. Lindgren E, Gustafson R. Tick-borne encephalitis in Sweden and climate change. Lancet. 2001;358:16-8.

33. Lindgren E, Talleklint L. Impact of climate change on the northern latitude limit an population densityof the diseasetransmitting European tick Ixodes ricinus. Environmental Health Perspectives. 2000;108:119-23.

34. Louis MES, Hess JJ. Climate Change Impacts on and Implications for Global Health. American Journal of Preventive 
Medicine. 2008;35(5):527-38.

35. McMichael AJ, Friel S, Nyong A, Corvalan C. Global environmental change and health: impacts, inequalities, and the health sector. British Medical Journal. 2008;336:191-4.

36. Furgal CM, Seguin J. Climate change, health and community adaptive capacity: lessons from the Canadian north. Environmental Health Perspectives. 2006; doi:10.1289/ehp.8433:available at http://dx.doi.org/, Online 11 July 2006.

37. Schmidhuber J, Tubiello F. Global food security under climate change. Proceedings of the National Academy of Science. 2007;104(50):19703-08.

38. McMichael A, Friel S, Nyong A, Corvalan C. Global environmental change and health: impacts, inequalities, and the health sector. British Medical Journal. 2008;336:191-94.

39. Charron D. Canada's response to the potential health threats of climate change Epidemiology. 2003;14(5):S138.

40. Charron D, Waltner-Toews D, Maarouf A. A Synopsis of Known and Potential Diseases and Parasites Associated with Climate Change, Paper. No. 154. Sault Ste. Marie, ON: Ontario Ministry of Natural Resources, Ontario Forestry Research Institute; 2003.

41. Health Canada. Canadian Climate Change and Health Vulnerability Assessment. Ottawa: Government of Canada; 2007.

42. Lemmen D, Warren F, Lacroix J, Bush E. From impacts to adaptation: Canada in a changing climate 2007. Ottawa: Government of Canada; 2008.

43. Mayewski PA, White F. The Ice Chronicles: The Quest to Understand Global Climate Change: University Press of New England 2002.

44. Environment Canada. Climate Change Scenarios Network. 2004 (cited 31 August 2007); Available from: http://www.ccsn.ca/index-e.html

45. Ford JD, Smit B, Wandel J, Allurut M, Shappa K, Qrunnut K, et al. Climate change in the Arctic: Current and future vulnerability in two Inuit communities in Canada. The Geographical Journal 2008;174(1):45-62.

46. Martello ML. Arctic indigenous peoples as representations and representatives of climate change. Social Studies of Science. 2008;38(3):351-76.

47. Furgal C, Prowse T. Northern Canada In: Lemmen D, Warren F, Bush E, Lacroix J, eds. From Impacts to Adaptation: Canada in a Changing Climate 2007. Ottawa Natural Resources Canada 2008.

48. Laidler G, Ford J, Gough WA, Ikummaq T, Gagnon A, Kowal S, et al. Assessing Inuit vulnerability to sea ice change in Igloolik, Nunavut. Climatic Change. In Press In Press.

49. Pearce $\mathrm{T}$, Ford $\mathrm{J}$, et al. Community collaboration and environmental change research in the Canadian Arctic. Polar Research. In Press;In Press

50. Doyon B, Belanger D, Gosselin P. The potential impact of climate change on annual and seasonal mortality for three cities in Quebec, Canada. International Journal of Health Geographics. 2008;7:23.

51. Koppe C, Jendritzky G, Kovats R, Menne B. Heat-waves: impacts and response. Copenhagen: World Health Organization; 2004.

52. Kunkel K, Changnon S, Reinke B, Arritt R. The July 1995 heat wave in the Midwest: a climatic perspective and critical weather factors. Bulletin of the American Meteorological Society. 1996;77(7):1507-18.

53. Bucker G. Vulnerable populations: lessons learnt from the summer 2003 heat waves in Europe. EuroSurveiallance. 2005;10(7):147.

54. Diaz J, Garcia R, Castro Fd, Hernandez E, Lopez C, Otero A. Effects of extremely hot days on people older than 65 years in
Seville (Spain) from 1986 to1997. International Journal of Biometeorology. 2002;463145-49.

55. Berrang-Ford L, Noble D. Climate change and health in Canadian municipalities. Environmental Health Review. 2007;50(4):109-15.

56. Charron D, Noble D. Public health implications of climate change. Municipal World. 2006; September 2006:45-6.

57. Campbell M, Cheng C. Differential and combined impacts of winter and summer weather and air pollution due to global warming on human mortality in south-central Canada. Ottawa: Health Canada, HPRP File No. 6795-15-2001/4400011; 2005.

58. Few R. Flooding, vulnerability and coping strategies: local responses to a global threat. Progress in Development Studies. 2003;3(1):43-58.

59. Hunter P. Climate change and waterborne and vector-borne disease. Journal of Applied Microbiology. 2003;94:37S-46S

60. Thomas M, Charron D, Waltner-Toews D, Maarouf A, J Holt JI, 167-180. The role of high impact weather in waterborne disease outbreaks in Canada. Journal Environmental Health Research. 2006;6:307.

61. Public Health Agency of Canada. Waterborne outbreak of gastroenteritis associated with a contaminated municipal water supply, Walkerton, Ontario, May-June 2000. Canada Communicable Disease Report. 2000;26(20):15 October 2000.

62. Ford JD, Smit B, Wandel J. Vulnerability to climate change in the Arctic: A case study from Arctic Bay, Canada. Global Environmental Change. 2006;16(2):145-60.

63. Berrang-Ford L, MacLean J, Gyorkos T, Ford J, Ogden N. Climate change and malaria in Canada: a systems approach. Interdisciplinary Perspectives on Infectious Diseases. 2009;2009:385487.

64. Nakazawa Y, Williams R, Peterson A, Mead P, Staples E, Gage $\mathrm{K}$. Climate change effects on plague and tularemia in the United States. Vector-borne and Zoonotic Diseases. 2007;7(4):529-40.

65. Ogden NH, Maarouf A, Barker IK, Bigras-Poulin M, Lindsay LR, Morshed MG, et al. Climate change and the potential for range expansion of the Lyme disease vector Ixodes scapularis in Canada. International Journal for Parasitology. 2006;36(1):6370.

66. Greer A, Ng V, Fisman D. Climate change and infectious diseases in North America: the road ahead. Canadian Medical Association Journal. 2008;178(6):715-22.

67. Rogers DJ, Packer MJ. Vector-borne diseases, models and global change. The Lancet. 1993;342:1282-4.

68. Charron D. Potential impacts of global warming and climate change on the epidemiology of zoonotic diseases in Canada. Can J Public Health. 2002;93(5):334-35.

69. Ogden NH, Barker IK, Beauchamp G, Brazeau S, Charron DF, Maarouf $\mathrm{A}$, et al. Investigation of ground level and remotesensed data for habitat classification and prediction of survival of Ixodes scapularis in habitats of southeastern Canada. J Med Entomol. 2006;43(2):403-14.

70. Ogden NH, Bigras-Poulin M, O'callaghan CJ, Barker IK, Kurtenbach K, Lindsay LR, et al. Vector seasonality, host infection dynamics and fitness of pathogens transmitted by the tick Ixodes scapularis. Parasitology. 2007;134(Pt 2):209-27.

71. Ogden NH, Trudel L, Artsob H, Barker IK, Beauchamp G, Charron DF, et al. Ixodes scapularis ticks collected by passive surveillance in Canada: analysis of geographic distribution and infection with Lyme borreliosis agent Borrelia burgdorferi. J Med Entomol. 2006;43(3):600-09.

72. Epstein P. West Nile Virus and the Climate. Journal of Urban Health. 2001;78(2):367-71.

73. Kunkel KE, Novak RJ, Lampman RL, Gu W. Modeling the impact of variable climatic facotrs on the crossover of Culex restauns and Cluex pipens (Diptera: culicidae), vectors of West 
NIle virus in Illinois. The American Journal of Tropical Medicine and Hygiene. 2006;74(1):168-73.

74. Kurz WA, Dymond CC, Stinson G, Rampley GJ, Neilson ET, Carroll AL, et al. Mountain pine beetle and forest carbon feedback to climate change. Nature. 2008;452(7190):987-90.

75. Tkacz B, Moody B, Castillo JV, Fenn ME. Forest health conditions in North America. Environmental Pollution. 2008;155(3):409-25.

76. Raffia K, Aukema B, Bentz B, Carroll A, Hicke J, Turner M, et al. Cross-scale drivers of natural disturbances prone to anthropogenic amplification: the dynamics of bark beetle eruptions. Bioscience. 2008;58(6):501-17.

77. Carroll A, Taylor S, Regniere J, Sfranyik L. Effects of climate change on range expansion by the mountain pin beetle in British Columbia. In: Shre T, Brooks J, Stone J, eds. Proceedings of the Mountain Pine Beetle Symposium: Challenges and Solutions, 30-31 October 2003, Kelowna, BC, Canada Information Report BC-X-399. Victoria, BC: Natural Resources Canada, Candian Forest Service, Pacific Forestry Centre 2004.

78. NR-CAN. Climate Change Impacts and Adaptation: A Canadian Perspective. Ottawa, CA: Natural Resources Canada (NRCAN); 2007.

79. Vescovi L, Rebetez M, Rong F. Assessing public health risk due to extremely high temperature events: climate and social parameters. Climate Research. 2005;30(1):71-8.

80. Ebi KL, Semenza JC. Community-Based Adaptation to the Health Impacts of Climate Change. American Journal of Preventive Medicine. 2008;35(5):501-7.

81. Keim ME. Building Human Resilience The Role of Public Health Preparedness and Response As an Adaptation to Climate Change. American Journal of Preventive Medicine. 2008;35(5):508-16.

82. Frumkin H, McMichael AJ, Hess JJ. Climate Change and the Health of the Public. American Journal of Preventive Medicine. 2008;35(5):401-2.

83. Furgal C, Seguin J. Climate change, health, and vulnerability in Canadian Northern Aboriginal communities. Environmental Health Perspectives 2006;114:1964-70.

84. Martin D, Belanger D, Gosselin P, Brazeau J, Furgal C, Dery S. Drinking water and potential threats to human health in Nunavik: Adaptation strategies under climate change conditions. Arctic. 2007;60(2):195-202.

85. Tong S, Mackenzie J, Pitman A, FitzGerald G, Nicholls N, Selvey L. Global climate change: time to mainstream health risk and their prevention on the medical research and policy agenda. Internal Medicine Journal. 2008;386a(445-47).

86. Campbell-Lendrum D, Corvalan C, Neira M. Global cliamte change: implications for international public health policy. Bull World Health Organ. 2007;85(3):161-244.

87. Ford JD, Pearce T, Smit B, Wandel J, Allurut M, Shappa K, et al. Reducing vulnerability to climate change in the Arctic: the case of Nunavut, Canada. Arctic 2007;60(2):150-66.

88. Pielke RA, Prins G, Rayner S, Sarewitz D. Climate change 2007: Lifting the taboo on adaptation. Nature. 2007;445:597-8.
89. Smit B, Wandel J. Adaptation, adaptive capacity, and vulnerability. Global Environmental Change. 2006;16:282-92.

90. Infrastructure Canada. Adapting infrastructure to climate change in Canada's cities and communities: a literature review.: Available at: http://www.infc.gc.ca/altformats/pdf/rs-rr-200612_02-eng.pdf; 2006.

91. Natural Resources Canada Climate Change Impacts and Adaptation Directorate. Adapting to Climate Change: An Introduction for Canadian Municipalities. Ottawa, Canada: Natural Resources Canada 2006.

92. Smit B, Pilifosova O. From adaptation to adaptive capacity and vulnerability reduction. In: Smith J, Klein RTJ, Huq S, eds. Climate change, adaptive capacity, and development. London: Imperial College Press 2003:356.

93. Gupta A, Moyer C, Sterm D. The economic impact of quarantine: SARS in Toronto as a case study. Journal of Infection. 2004;50(5):386-93.

94. Varia M, Wilson S, Sarwal S, McGeer A, Gournis E, Galanis E, et al. Investigation of a nosocomial outbreak of severe acute respiratory syndrome (SARS) in Toronoto, Canada. Canadian Medical Association Journal. 2003;169(4):285-92.

95. Newman R, Barber A, Roberts J, Holtz T, Steketee R, Parise M. Malaria Surveillance -- United States, 1999. MMWR. 2002;51(SS01):15-28.

96. Johnston B, Conly J. West Nile virus - where did it come from and where might it go? Canadian Journal of Infectious Diseases. 2000;11(4):175-78.

97. Feldmann H, Czub M, Jones S, Dick D, Garbutt M, Grolla A, et al. Emerging and re-emerging infectious diseases. Mecial Microbiology and Immunology. 2002;191:63-74.

98. MacLean JD, Demers AM, Ndao M, Kokoskin E, Ward BJ, Gyorkos TW. Malaria epidemics and surveillance in Canada. Emerging Infect Dis. 2004;10(7):1195-201.

99. Bouma M, Kaay Hvd. The El Niño Southern Oscillation and the historic malaria epidemics on the Indian subcontinent and Sri Lanka: an early warning system for future epidemics? Tropical Medicine and International Health. 1996(86-96).

100. Bouma M, Dye C, Kaay Hvd. Falciparum malaria and climate change in the northwest frontier province of Pakistan. Am J Trop Med Hyg. 1996;55(2):131-7.

101. Stern N. Stern Review on the Economics of Climate Change. London, UK: HM Treasury. Available at: http://www.hmtreasury.gov.uk/stern_review_report.htm; 2006.

102. CNA/CMA. Joint CNA/CMA Position Statement on Environmentally Responsible Activity in the Health Sector.: Canadian Nurses Association (CNA) and the Canadian Medical Association (CMA). Available at: http://www.cnaaiic.ca/CNA/documents/pdf/publications/PS33_Joint_Stat_Env ir_Resp_Activity_Health_Sector_Feb_2006_e.pdf 2005.

103. World Bank. Health, Nutrition and Population (HNP) Stats. 2005 (cited 24 Feb. 09); Available from: http://web.worldbank.org

Dr. Lea Berrang Ford is an Assistant Professor of Health Geography in the Department of Geography at McGill University. Dr. Berrang Ford holds degrees in Geography (BSc), Environmental Change (Oxford, UK), and Epidemiology (Guelph, CA). Her research focuses on the impact of environmental change on human health, with expertise in ecosystem approaches to human health, infectious vector-borne and zoonotic disease epidemiology, and spatial analysis. 